\title{
Anti-interleukin 2 receptor antibody attenuates low-dose streptozotocin-induced diabetes in mice
}

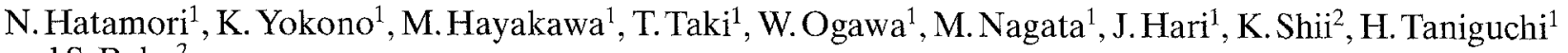 \\ and S. Baba ${ }^{2}$ \\ ${ }^{1}$ Second Department of Internal Medicine, Kobe University School of Medicine, Kobe, and ${ }^{2}$ Hyogo Institute for Research in Adult \\ Diseases, Akashi, Japan
}

\begin{abstract}
Summary. Recent evidence indicates that activated $T$ cells and macrophages play an important role in the induction of insulitis and diabetes in certain strains of mice treated with multiple subdiabetogenic doses of streptozotocin. In the present study, we treated C57BL/6J mice with five daily doses of $40 \mathrm{mg} / \mathrm{ml}$ streptozotocin and examined the prophylactic effect of an anti-interleukin 2 receptor monoclonal antibody (PC61). In mice treated with streptozotocin, interleukin 2 receptor-positive mononuclear cells were shown to infiltrate into the islets and soluble interleukin 2 receptors in the sera were significantly increased compared with control mice. The administration of PC61 to the mice attenuated the insulitis, and diminished interleukin 2 receptor-positive cells from islets and soluble interleukin 2 receptors in the sera. Moreover, the administration of PC61 significantly reduced the development of hyperglycaemia shown in these mice $(12.8 \pm 1.1 \mathrm{mmol} / \mathrm{l}$ vs $18.5 \pm 0.7 \mathrm{mmol} / 1, p<0.005)$. As judged
\end{abstract}

by flow cytometric analysis, this antibody did not cause any changes in either spleen cell counts or $\mathrm{T}$ cell subsets. Interleukin 2 receptors were expressed on a minor population of spleen cells regardless of treatment with PC61 (STZ + normal rat IgG: $2.1 \pm 0.3 \%$, STZ + PC61: $2.4 \pm 0.3 \%)$. Even after stimulation of spleen cells with concanavalin $\mathrm{A}$ or alloantigen, interleukin 2 receptor expression was not significantly different between the two groups. Our studies suggest that interleukin 2 receptor-positive activated $T$ cells or macrophages are important in the development of multi-low-dose streptozotocin diabetes and that an anti-interleukin 2 receptor antibody can attenuate this process.

Key words: Type 1 (insulin-dependent) diabetes, streptozotocin, interleukin 2 receptor, anti-interleukin 2 receptor antibody, soluble interleukin 2 receptor.
Multiple low-dose streptozotocin (STZ)-induced diabetes develops in a strain-dependent manner often in conjunction with a cellular infiltration of the pancreatic islets (insulitis) [1-3]. Recent studies have suggested that cell-mediated immune mechanisms play an important role in the pathogenesis of this model of diabetes [4-10]. Diabetes can be prevented by treatment with anti-T cell antibodies [11] or an H-2 alloantiserum [12]. Furthermore, the development of STZ-induced diabetes is prevented by total-body irradiation, with diabetes developing after adoptive replacement of T cells [7-10]. Macrophages can also infiltrate into the islets in the early stage of insulitis as shown by immunohistochemistry and diabetes can be prevented by administration of silica particles [13].

Interleukin 2 (IL2) is produced by antigen- or mitogen-activated $\mathrm{T}$ cells and plays a central role in the development of the immune response [14]. As with other classic peptide hormones, IL2 is thought to act on T cells or macrophages through its own receptor [15]. IL2 and its surface receptor (IL2R) have proved to be essential to the growth and proliferation of the effector cells of immunity. There exist two classes of IL2R with high and low affinity, and all the positive biological effects of IL2 appear to be mediated by high affinity IL2R [16]. High affinity IL2R is only transiently expressed upon lymphocytes during the antigen-driven proliferative burst.

In the present study, to clarify the pathogenic significance of IL2R-positive activated T cells or macrophages in diabetes induced by STZ, we have examined whether treatment with an anti-IL2R monoclonal antibody, which recognizes the 55-kilodalton (kD) subunit of the high affinity heterodimetric IL2R [17], could suppress insulitis and diabetes in this animal model of Type 1 (insulin-dependent) diabetes.

\section{Materials and methods}

Mice

Eight- to 12 week-old male C57BL/6J ( $\mathrm{H}-2^{\mathrm{b}}$ haplotype) and BALB/c (H-2d haplotype) mice were purchased from Clea Co. (Osaka, Japan) and bred at the Experimental Animal Centre, Kobe University School of Medicine, in a specific pathogen-free state.

\section{$S T Z$}

STZ(Upjohn Chemical Company, Kalamazoo, Mich, USA) was dissolved in $25 \mathrm{mmol} / 1 \mathrm{NaCl}$ acidified to $\mathrm{pH} 4.0$ with $50 \mathrm{mmol} / 1 \mathrm{citric}$ acid and injected i.p. into mice within $10 \mathrm{~min}$ at a dose of $40 \mathrm{mg} / \mathrm{kg}$ body weight on five consecutive days. 


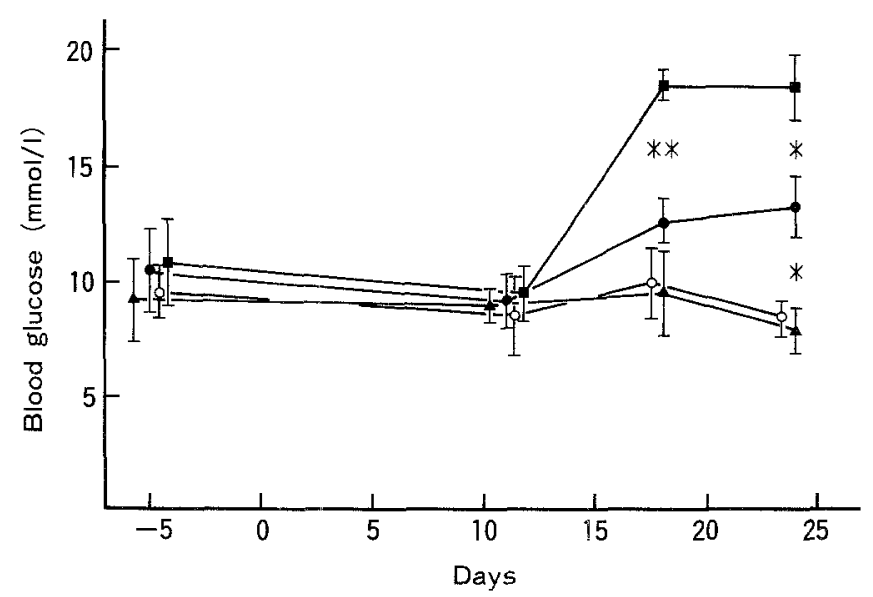

Fig.1. Plasma glucose levels in mice after being given streptozotocin (STZ) and anti-interleukin 2 receptor antibody (PC61). STZ was administered on days $1-5$. Purified immunoglobulin $(1 \mathrm{mg} / \mathrm{kg}$ body weight) was injected i. p. on days $-5,-2$ and $1-10$. Plasma was collected for measurement of the nonfasting glucose concentration by the glucose oxidase method. ( ) STZ + normal rat $\operatorname{IgG}(n=8)$; ( STZ + PC61 $(n=8)$, (O) PC61 $(n=5) ;(\boldsymbol{\Delta})$ buffer alone $(n=5)$. $*$ and ** show $p<0.02$ and $p<0.005$, respectively

\section{Monoclonal anti-IL2R antibody}

The PC61 hybridoma was obtained from American Type Culture Collection (Rockville, Md, USA). The hybridoma secretes a rat monoclonal $\mathrm{Ig}_{1}$ antibody which is specific for the mouse IL2R, and the antibody inhibits the binding of IL2 to both the high- and low-affinity receptors [17] and the IL2-dependent proliferation of activated $T$ and $B$ cells [18]. Among several monoclonal anti-mouse IL2R antibodies, PC61 antibody is reported to be the most efficient inhibitor of IL 2 binding to the receptor and IL2-induced T cell proliferation [19]. Antibody from concentrated culture supernatants or normal rat IgG from rat serum was purified by affinity chromatography on protein A-Sepharose 4B (Pharmacia, Uppsala, Sweden). One $\mathrm{mg} / \mathrm{kg}$ body weight of purified immunoglobulin was injected i. p. two and five days before the STZ administration and on days one to ten. (The day of the first STZ injection was designated day 1.)

\section{Experimental design}

The mice were divided into four groups. Group 1 comprised mice injected with buffer alone $(n=5)$. Group 2 comprised mice treated with PC61 $(n=5)$. Group 3 comprised STZ-injected mice treated with normal rat IgG $(n=8)$. Group 4 comprised STZ-injected mice treated with PC61 $(n=8)$. Nineteen days after the last injection of STZ, all of the mice were killed. Plasma was collected for measurement of the nonfasting glucose concentration by the glucose oxidase method. Their body weights did not significantly differ between treatment groups. The spleens and pancreas were collected for measurement of lymphocyte subpopulations and histologic examinations, respectively.

\section{Pancreas histology and immunohistochemical staining}

For histological examinations, the pancreata were fixed in Bouin's solution at death, and $3 \mu \mathrm{m}$ sections were stained with haematoxylin and eosin. All slides were coded and evaluated for the incidence of insulitis by two operators blinded to the experimental protocol. Tissues for immunohistochemistry were snap frozen in liquid $\mathrm{N}_{2}$ and stored at $-70^{\circ} \mathrm{C}$. The cryostat sections $(6 \mu \mathrm{m})$ of these pancreata were fixed in acetone for $10 \mathrm{~min}$ at room temperature and washed three times with phosphate-buffered saline (PBS; $20 \mathrm{mmol} / 1 \mathrm{Na}_{2} \mathrm{HPO}_{4}, 20 \mathrm{mmol} / \mathrm{l}$ $\left.\mathrm{NaH}_{2} \mathrm{PO}_{4}, 150 \mathrm{mmol} / \mathrm{I} \mathrm{NaCl}, \mathrm{pH} 7.4\right)$. The sections were incubated for
$1 \mathrm{~h}$ at room temperature with PC61 $(20 \mu \mathrm{g} / \mathrm{ml})$ diluted with PBS containing $1 \%$ bovine serum albumin (PBS/BSA). After washing, they were incubated for 30 min at room temperature with fluorescein-conjugated goat anti-rat immunoglobulin (Cooper Biomedical Inc., Malvern, $\mathrm{Pa}, \mathrm{USA}$ ) at 1:100 dilution in PBS/BSA. A fluorescence microscope equipped with epi-illumination (Olympus, BH-2 type, Tokyo, Japan) was used for the assessment of the reaction.

\section{Sandwich RIA of soluble IL2R}

Soluble IL2R levels were assessed by the sandwich RIA. Briefly, $96-$ well microtitre plates (Flow Laboratories, McLean, Va, USA) were coated at $4^{\circ} \mathrm{C}$ overnight with $50 \mu \mathrm{l}$ of 7D4 (rat IgM monoclonal antimouse IL2R antibody, $20 \mu \mathrm{g} / \mathrm{ml}$ ), which binds to a different epitope of the IL2R and does not compete with IL2 or PC61, in carbonate buffer (20 mmol// $\mathrm{NaHCO}_{3}, 20 \mathrm{mmol} / 1 \mathrm{Na}_{2} \mathrm{CO}_{3}, \mathrm{pH}$ 9.6) [20]. After washing with $20 \mathrm{mmol} / \mathrm{PBS}$ containing $0.1 \% \mathrm{BSA}$ and $0.05 \%$ Tween 20 and saturation to block nonspecific binding with $20 \mathrm{mmol} / \mathrm{l}$ PBS containing $1 \% \mathrm{BSA}, 50 \mu \mathrm{l}$ of each serum sample was added to the well in twofold serial dilutions. After incubation at $4^{\circ} \mathrm{C}$ overnight and further washing, ${ }^{125} \mathrm{I}-\mathrm{PC} 61$ (approximately $200000 \mathrm{cpm} /$ well, specific activity; $13 \mu \mathrm{Ci} / \mu \mathrm{g}$ ), which was iodinated by chloramine $\mathrm{T}$ method [21], in $20 \mathrm{mmol} / \mathrm{l}$ PBS containing $1 \%$ BSA was added and incubated at room temperature for $2 \mathrm{~h}$. After unbound radioactivities were removed by washing, wells were cut and their radioactivities were counted by $\gamma$-counter. Solubilized CTLL-2 (murine IL2 dependent T cell-line) extracts derived from $10^{8} \mathrm{cells} / \mathrm{ml}$ were arbitrarily assigned a concentration of 1000 soluble IL $2 \mathrm{R} \mathrm{U} / \mathrm{mI}$ and were used as internal standards. The cell extracts were produced by lysing CTLL-2 at a concentration of $10^{8}$ cells $/ \mathrm{ml}$ in $10 \mathrm{mmol} / \mathrm{LBS}$ which contained $1 \%$ Triton X-100 and $2 \mathrm{mmol} / \mathrm{l}$ phenylmethylsulphonyl fluoride.

Table 1. Suppression of insulitis and diabetes in mice given streptozotocin (STZ) by anti-interleukin 2 receptor (IL2R) antibody

\begin{tabular}{|c|c|c|c|}
\hline \multirow[t]{2}{*}{ Treatment } & Insulitis-positive islets & $(\%)$ & Plasma glucose \\
\hline & \multicolumn{2}{|c|}{ Total islets examined } & \\
\hline \multicolumn{4}{|c|}{ STZ+ anti-IL2R antibody (PC61) } \\
\hline 1 & $12 / 48$ & $(25.0)$ & 13.3 \\
\hline 2 & $12 / 55$ & $(21.8)$ & 19.4 \\
\hline 3 & $9 / 54$ & $(16.7)$ & 12.5 \\
\hline 4 & $6 / 30$ & $(20.0)$ & 11.9 \\
\hline 5 & $8 / 48$ & $(16.7)$ & 12.8 \\
\hline 6 & $6 / 30$ & $(20.0)$ & 11.1 \\
\hline 7 & $0 / 33$ & $(0.0)$ & 8.6 \\
\hline \multirow[t]{2}{*}{8} & $5 / 30$ & $(16.7)$ & 12.5 \\
\hline & & $17.1 \pm 2.7^{\mathrm{a}}$ & $12.8 \pm 1.1^{\mathrm{b}}$ \\
\hline \multicolumn{4}{|c|}{ STZ + normal rat IgG } \\
\hline 1 & $29 / 39$ & $(74.4)$ & 21.1 \\
\hline 2 & $20 / 32$ & $(62.5)$ & 18.6 \\
\hline 3 & $12 / 15$ & $(80.0)$ & 16.9 \\
\hline 4 & $24 / 33$ & $(72.7)$ & 18.3 \\
\hline 5 & $15 / 17$ & (88.2) & 20.8 \\
\hline 6 & $33 / 42$ & $(78.6)$ & 15.5 \\
\hline 7 & $29 / 39$ & $(74.4)$ & 17.5 \\
\hline \multirow[t]{2}{*}{8} & $22 / 32$ & $(68.8)$ & 18.9 \\
\hline & & $75.0 \pm 2.7$ & $18.5 \pm 0.7$ \\
\hline
\end{tabular}

Nineteen days after the last injection of STZ, all of the mice were killed. Each pancreas was collected for histological examination. Plasma was collected for measurement of the nonfasting glucose concentration by the glucose oxidase method on day 18 . The mean level of plasma glucose and the ratio of insulitis-positive islets/total islets examined in the five negative control mice (buffer alone) were $9.6 \pm 2.8 \mathrm{mmol} / 1$ and $0 \%(0 / 217)$, respectively.

${ }^{\mathrm{a}}$ and ${ }^{\mathrm{b}}$ show $p<0.001$ and $p<0.005$ vs STZ + normal rat $\mathrm{IgG}$, respectively 


\section{Measurement of splenic cell subpopulations}

Spleen mononuclear cells were obtained by Ficoll gradient centrifugation. Spleen cell suspensions were washed in Dulbecco's PBS $\left(137 \mathrm{mmol} / / \mathrm{NaCl}, 3 \mathrm{mmol} / 1 \mathrm{KCL}, 8 \mathrm{mmol} / \mathrm{l} \mathrm{Na} \mathrm{HPO}_{4}, 1 \mathrm{mmol} / \mathrm{l}\right.$ $\mathrm{KH}_{2} \mathrm{PO}_{4}, \mathrm{pH} 7.4$ ) containing $1 \%$ fetal calf serum (Gibco, Grand Island, NY, USA) and $0.1 \%$ sodium azide. The cell surface staining was carried out by incubation with fluorescein isothiocyanate (FITC)-conjugated monoclonal anti-Thy1.2 and Lyt2 antibodies, and phycoerythrin (PE)-conjugated monoclonal anti-L3T4 antibody (Becton Dickinson, Monoclonal Center, Mountain View, Calif, USA) for $30 \mathrm{~min}$ at $4^{\circ} \mathrm{C}$ using $4 \mu \mathrm{l}$ of antibody per $10^{6}$ cells. Samples were analysed on a FACS 440 flow cytometer (Becton. Dickinson).

\section{Analysis of IL2R expression on spleen cells}

Spleen cells were stimulated with mitogen (concanavalin A; ConA) or alloantigen (BALB/c spleen cells). Briefly, spleen cells were resuspended at a final concentration of $2 \times 10^{6}$ cells $/ \mathrm{ml}$ in RPMI $1640 \mathrm{me}-$ dium containing $10 \%$ fetal calf serum and supplemented with $2 \mathrm{mmol} / \mathrm{l}$ glutamine, $2 \mathrm{mmol} / \mathrm{l}$ sodium pyruvate, $50 \mathrm{U} / \mathrm{ml}$ penicillin, $50 \mu \mathrm{g} / \mathrm{ml}$ streptomycin (Flow Laboratories) and $50 \mu \mathrm{mol} / 12$-mercaptoethanol (Wako Pure Chemicals, Osaka, Japan), and then stimulated with either $2.5 \mu \mathrm{g} / \mathrm{ml}$ ConA (Sigma Chemicals Co., St.Louis, Mo, USA) for 3 days or mitomycin C-treated BALB/c spleen cells $\left(2 \times 10^{6} \mathrm{cells} / \mathrm{ml}\right)$ for 6 days reconstituted in the culture medium described above. After incubation in a humidified atmosphere of $5 \%$ $\mathrm{CO}_{2}$ in air at $37^{\circ} \mathrm{C}$, each activated spleen cell was harvested by centrifugation. Both non-activated and activated spleen cells were suspended in the staining buffer (Dulbecco-PBS, 1\% fetal calf serum, $0.1 \%$ sodium azide) and incubated with PC61 antibody (final concentration: $5 \mu \mathrm{g} / \mathrm{ml}$ ) for $30 \mathrm{~min}$ at $4^{\circ} \mathrm{C}$. After two washing steps, $5 \mu \mathrm{l}$ of a goat anti-rat fluorescein-conjugated immunoglobulin ( $1: 10$ dilution) was added and incubated for $30 \mathrm{~min}$ at $4^{\circ} \mathrm{C}$. Cell suspensions were then washed twice and resuspended in the staining buffer. Control samples were stained with the fluorescent conjugate alone. Antibody-reacted cell suspensions were analysed on an FACS 440 flow cytometer. The number of PC61-positive cells was determined by integrating 10000 cell logarithmic fluorescence histogram above the channel in which no appreciable fluorescence was seen for the negative controls.

\section{Statistical analysis}

Results are given as mean \pm SEM. Statistical significance was determined with Mann-Whitney U-test. A $p$ value of $<0.05$ was considered statistically significant.

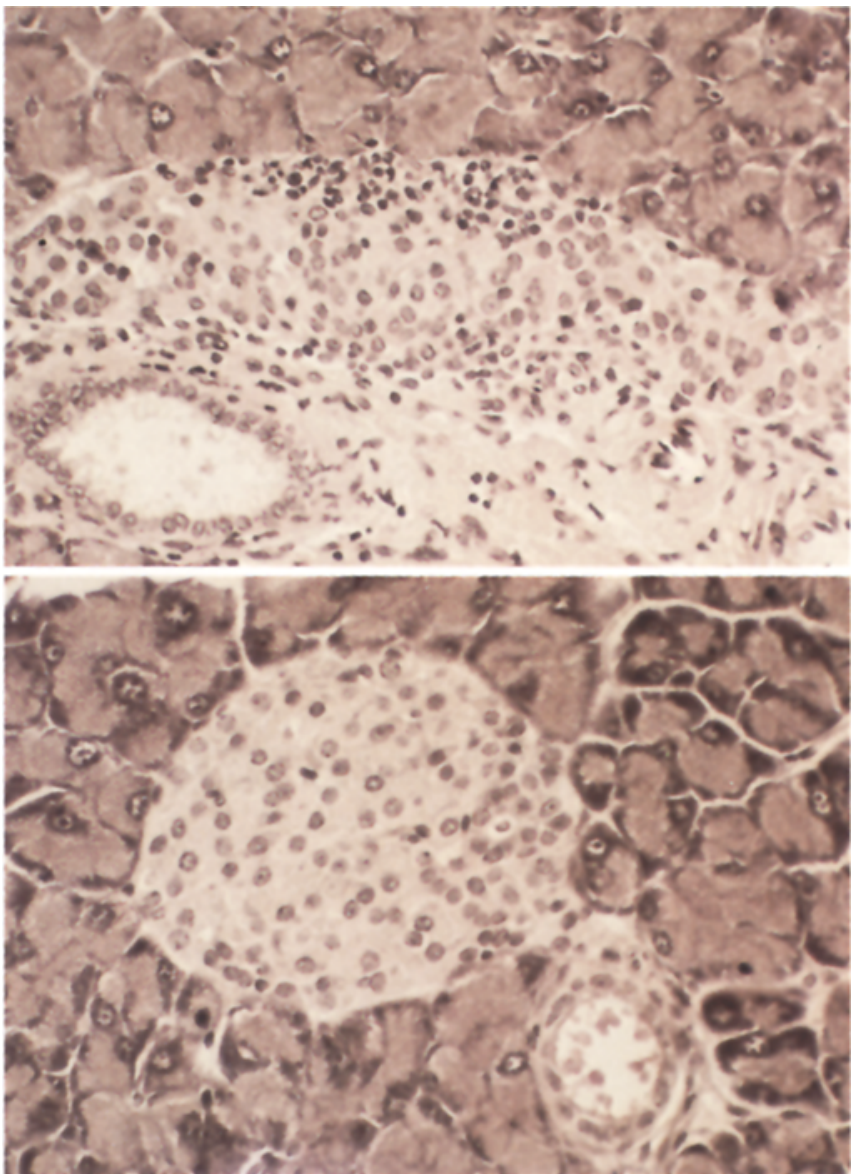

Fig. 2. Section through islets in the pancreas of $\mathrm{C} 57 \mathrm{BL} / 6 \mathrm{~J}$ male mice treated with streptozotocin and IgG. Upper panel shows a pancreatic islet of a littermate mouse injected with normal rat IgG. Note the inflammatory cells infiltrate within the islet. Lower panel shows an islet in the pancreas of a mouse treated with anti-interleukin 2 receptor antibody (PC61)

\section{Results}

Induction of diabetes mellitus in C57BL/6J mice with multiple doses of STZ

Administration of five daily injections of STZ induced hyperglycaemia in C57BL/6J mice treated with normal rat IgG (Fig.1). On day 18, the mean plasma glucose level rose to $18.5 \pm 0.7 \mathrm{mmol} / \mathrm{l}$ in mice given STZ compared

Table 2. Effect of monoclonal anti-interleukin 2 receptor antibody on the proportion of T cell subsets and interleukin 2(IL2R) receptor-positive cells in splenic mononuclear cells

\begin{tabular}{|c|c|c|c|c|c|c|}
\hline \multirow[t]{2}{*}{ Group } & \multirow[t]{2}{*}{$n$} & \multirow{2}{*}{$\begin{array}{l}\text { Cell number } \\
\left(\times 10^{6}\right)\end{array}$} & \multicolumn{4}{|c|}{$\%$ Positive cells } \\
\hline & & & Thy1.2 & Lyt2 & L3T4 & IL2R \\
\hline Buffer alone & 5 & $5.1 \pm 1.8$ & $43.4 \pm 7.8$ & $15.9 \pm 1.9$ & $22.4 \pm 1.1$ & $1.9 \pm 0.5$ \\
\hline PC61 & 5 & $5.3 \pm 2.0$ & $43.3 \pm 9.7$ & $17.5 \pm 1.1$ & $23.5 \pm 3.1$ & $1.8 \pm 0.4$ \\
\hline STZ + PC61 & 8 & $6.0 \pm 2.5$ & $38.0 \pm 3.8$ & $13.3 \pm 1.7$ & $21.3 \pm 1.4$ & $2.4 \pm 0.3$ \\
\hline
\end{tabular}

Splenic mononuclear cells from each group were stained with fluorescein isothiocyanate-conjugated monoclonal anti-Thyl.2 and Lyt 2 antibodies, and phycoerythrin-conjugated monoclonal anti-L3T4 antibody. Furthermore, indirect immunofluorescence analysis was done with a rat anti-IL2R monoclonal antibody (PC61) and a goat anti-rat fluorescein-conjugated immunoglobulin. Samples were analysed on a FACS 440 flow cytometer. No significant differences were shown between each group.

$\mathrm{STZ}=$ streptozotocin 


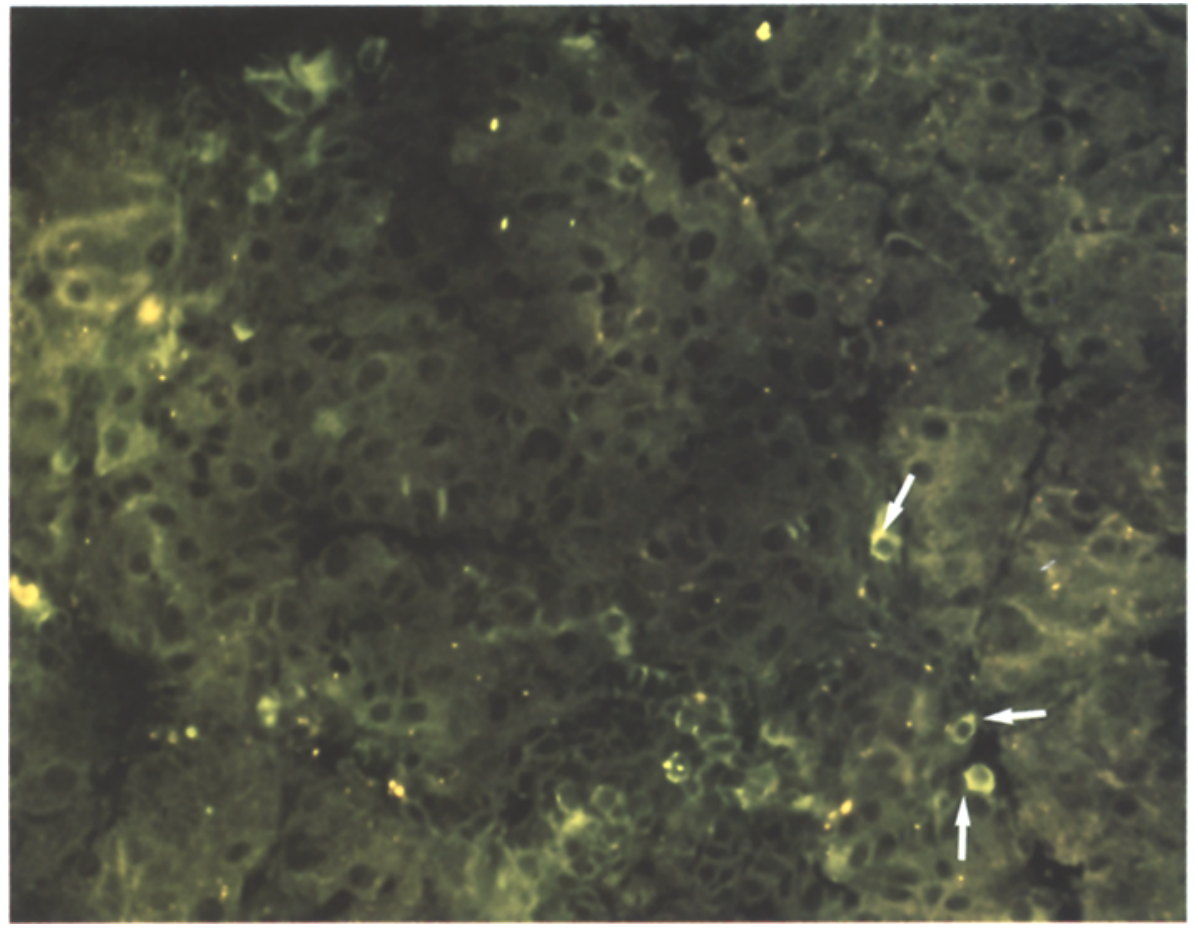

Fig. 3. Cryostat sections of the pancreata obtained from streptozotocin

(STZ)-injected mice treated with either normal rat IgG or PC61 were stained by indirect immunofluorescence with antibodies as described in Materials and methods. Note interleukin 2

receptor-positive cells infiltrate into the islet of pancreas from mice treated with STZ + normal rat IgG. One experiment representative of five is shown. No fluorescence-positive cells were seen in the islet from mice treated with STZ + PC61 (data not shown) with $9.6 \pm 1.8 \mathrm{mmol} / 1$ in mice given citrate buffer alone $(p<0.001)$. Mononuclear cell infiltration (insulitis) was seen in pancreatic islets from mice treated with STZ and normal rat IgG (Fig. 2, upper panel). Furthermore, tissue sections of pancreas were stained with anti-IL2R antibody to determine whether IL2R-positive activated cells were present within the cellular infiltration in the islets. Immunohistochemical study revealed that IL2R-positive mononuclear cells infiltrated into the islets from mice given STZ (Fig.3). Soluble IL2R levels in the sera from mice treated either with or without STZ were examined by the sandwich RIA. Figure 4 shows the time course of mean values of soluble IL2R levels per group. Treatment of C57BL/6J mice with multiple low dose STZ caused an increase of soluble IL2R around day 11 and a continuous rise until day 24.

\section{Effect of treatment with anti-IL2R antibody (PC61)}

As shown in Figure 1, PC61 itself did not show any effects on glucose tolerance. Administration of PC61 $(1 \mathrm{mg} / \mathrm{ml}$, days $-5,-2$, and $1-10$ i.p.) significantly reduced the development of hyperglycaemia induced by STZ on days 18 $(p<0.005)$ and $24(p<0.02)$. Even without the preceding injection of PC61 (PC61 was injected on days 1-10), the hyperglycaemia was attenuated to the same extent as the present experimental design (data not shown). Furthermore, histological examination revealed that this treatment attenuated the insulitis and diminished IL2R-positive cells from islets (Fig.2, lower panel). Table 1 summarizes the incidence of insulitis-positive islets in each pancreas and the levels of plasma glucose on day 24 and 18 , respectively. The incidence of insulitis-positive islets in STZ-injected mice treated with PC61 $(17.1 \pm 2.7 \%)$ was significantly decreased $(p<0.001)$ compared with that in control mice treated with normal rat $\operatorname{IgG}$ $(75.0 \pm 2.7 \%)$. Among the eight PC61-treated mice, only one mouse did not develop any evidence of insulitis and showed normoglycaemia. To determine the effect of treatment with PC61 on T cell subpopulations and IL2R-positive cells, spleen cells from each group were stained with monoclonal antibody to Thy1.2, L3T4 or Lyt2, or monoclonal PC61 antibody, and the relative number of cells stained with these antibodies was determined by flow cytometry. As shown in Table 2, PC61 did not cause any changes in spleen cell counts, T cell subsets and IL2Rpositive cells. To investigate whether treatment with PC61 has any effects on non-specific IL2R expression, IL2R expression on spleen cells was examined under stimulatory conditions. IL2R-positive cells after stimulation with mitogen or alloantigen were followed; buffer alone: $39.4 \pm 1.7 \%, 28.9 \pm 2.2 \%$; PC61: $42.3 \pm 4.4 \%, 27.1 \pm 1.9 \%$; $\mathrm{STZ}+$ normal rat $\mathrm{IgG}: \quad 41.7 \pm 2.7 \%, \quad 30.9 \pm 2.9 \%$; STZ + PC61: $44.6 \pm 3.5 \%, 31.9 \pm 1.4 \%$, respectively.

Thus, IL2R-positive spleen cells were greatly increased. However, no significant difference could be seen in the number of PC61-positive cells between the four groups. On the contrary, the levels of soluble IL2R were decreased to near normal levels by the treatment with PC61 (Fig.4).

\section{Discussion}

IL2 is a T cell-derived lymphokine that has been shown to exert its biological effects via interaction with specific cellsurface receptors $[22,23]$. While resting $T$ cells and macrophages express few if any IL2R, activation of these cells with mitogens or specific antigens leads to marked expression of IL2R $[24,25]$. In the present study, multiple low doses of STZ induced insulitis and overt diabetes in 


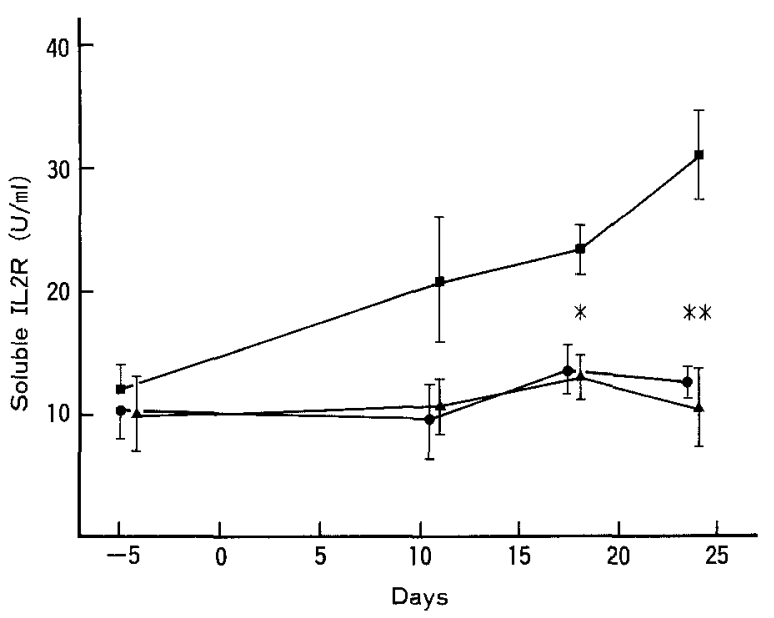

Fig.4. Detection of soluble interleukin 2 receptor (IL2R) in the sera of multi-low dose streptozotocin (STZ) mice. (v) STZ + normal rat $\operatorname{IgG}(n=8) ;(\bullet) \mathrm{STZ}+\mathrm{PC} 61(n=8) ;(\boldsymbol{\Delta})$ buffer alone $(n=5)$. $*$ and $* *$ show $p<0.02$ and $p<0.005$ vs STZ + PC61 and buffer alone, respectively

C57BL/6J mice, and IL2R-positive mononuclear cells were present within the cellular infiltration in the islets of these mice. Since anti-IL2R antibody (PC61) could attenuate the insulitis and reduce the development of hyperglycaemia, IL2R-positive cells in the islets appear to play an important role in the development of diabetes after multiple injections of STZ. However, PC61 could neither prevent the insulitis completely nor suppress hyperglycaemia to normoglycaemia. Although the mechanisms are currently unclear, several explanations have to be considered. Kolb et al. reported that macrophage-dependent single cell insulitis probably progresses to lymphocytic insulitis (multicellular insulitis) in STZ-induced islet inflammation $[13,26]$ and the administration of macrophage toxic silica particles almost completely prevents diabetes development $[13,27]$. They also reported that depletion of total $\mathrm{T}$ cells by administration of monoclonal antibody to Thy1 suppressed the development of hyperglycaemia [27]. These results indicate a role for $T$ cells besides macrophages in Beta-cell destruction. Furthermore, it was reported that other cell types rather than $\mathrm{T}$ cells and macrophages exist in the islet $[26,28]$, especially natural killer cells which are predominantly seen in the islet [28], suggesting that natural killer cells may also contribute to the destruction of Beta cells as shown in BB rats $[29,30]$. Although these three immune cell types are reported to express IL2R on their cell surface [31,32], these cells may show differential sensitivity to PC61. It is conceivable, therefore, that one or two of these cell types is not be fully suppressed by PC61. As suggested by Rossini et al., the induction of diabetes in this model may involve an initial toxic injury followed by immunological mediated insulitis [3]. Treatment with anti-IL2R antibody, which is directed against the latter, would not prevent the toxic effects of STZ. Some Beta-cell impairment induced by toxic effect may explain the relatively elevated glucose levels in STZinjected mice treated with PC61.

We have examined the effects of PC61 on spleen cell subpopulations and the capacity of IL2R expression on spleen cells. Administration of PC61 did not show any effects on spleen cell subpopulations or IL2R expression. On the other hand, autoimmune diabetes induced by multiple low doses of STZ was also successfully treated with monoclonal antibodies against $\mathrm{T}$ cells. However, in this case, administration of anti-L3T4 or anti-Lyt2 antibody was reported to cause a reduction in each splenic $T$ cell subset [11]. Although these antibodies bind to most mouse T cells, anti-IL2R antibody binds to only antigenspecific activated cells. Furthermore, IL2R are only transiently expressed upon lymphocytes during the antigendriven proliferative burst, whereas L3T4 and Lyt2 molecules are continually expressed. As shown in Table 2, very few populations of IL2R-positive cells in the STZtreated mouse spleen $(<2.5 \%)$ may also account for the finding that no significant reduction of the splenic $\mathrm{T}$ cell subsets was observed the treatment with PC61. In addition, no significant difference of IL2R-positive cells between each group may be interpreted by the possibility that transient alterations due to PC61 might recover prior to the collection of the sample for flow cytometry.

Recent studies using an enzyme-linked immunosorbent assay have demonstrated that a part of IL2R can be released from the cell-surface when stimulated by antigen or mitogen [33]. In the present study, soluble IL2R were examined in the sera from mice given STZ. The levels of soluble IL2R were significantly elevated by multiple injections of STZ $(p<0.005)$. Rubin et al. have hypothesized that soluble IL2R release by activated lymphocytes may play an immunoregulatory role by competing with the cellular IL2R to such an extent as to affect immune response [33]. Keller et al. reported that depressed levels of soluble IL2R were observed in newly-diagnosed Type 1 (insulin-dependent) diabetes, suggesting a failure of immunosuppression [34]. On the contrary, Giordano et al. indicated that soluble IL2R were elevated in the sera, whereas a significant decrease was observed in supernatants of phytohaemagglutinin-stimulated lymphocytes from Type 1 diabetes [35]. Moreover, elevated levels of soluble IL2R have been identified in transplantation rejection [36] and several autoimmune diseases such as systemic lupus erythematosus [37] and rheumatoid arthritis [38]. Thus, although IL2R expression in Type 1 diabetes remains obscure, the elevated soluble IL $2 \mathrm{R}$ in the sera seems to reflect not only immunosuppression but also the activation of Beta-cell specific immune cells. The elevated levels of soluble IL2R in STZ-injected mice were recovered to control levels by the PC61 treatment, suggesting that injected PC61 antibody is biologically active and appears to reduce the number or the activity of IL2R-positive cells. Although further studies are necessary to clarify the effects of this antibody, the present study revealed that treatment with anti-IL2R antibody might be an ideal method to diminish the autoreactive clones while sparing the other immunocompetent cells.

Acknowledgements. The authors wish to thank Dr. K. Doi, Department of Internal Medicine, Metabolic Unit, Kobe University School of Medicine, for valuable advice and use of the flow cytometer. This work was supported in part by Grand-in-aid for scientific research 61480251 from the Japanese Ministry of Education, Science and Culture. 


\section{References}

1. Rossini AA, Appel MC, Williams RM, Like AA (1977) Genetic influence of the streptozotocin-induced insulitis and hyperglycemia. Diabetes 26: 916-920

2. Leiter E (1982) Multiple low-dose streptozotocin-induced hyperglycemia and insulitis in C57BL mice: influence of inbred background, sex, and thymus. Proc Natl Acad Sci USA 79: 630634

3. Rossini A, Mordes J, Like A (1985) Immunology of insulin-dependent diabetes mellitus. Annu Rev Immunol 3: 289-320

4. McEvoy RC, Andersson J, Sandler S, Hellerström C (1984) Multiple low-dose streptozotocin-induced diabetes in the mouse: evidence for stimulation of a cytotoxic cellular immune response against an insulin-producing beta cell line. J Clin Invest 74: 715-722

5. Rossini A, Like A, Chick W, Appel M, Cahill GL (1977) Studies of streptozotocin-induced insulitis and diabetes. Proc Natl Acad Sci USA 74: 2485-24.89

6. Kiesel U, Kolb H (1983) Suppressive effect of antibodies to immune response gene products on the development of low-dose streptozotocin-induced diabetes. Diabetes 32: 869-871

7. Rossini AA, Williams RM, Appel MC, Like AA (1978) Complete protection from low-dose streptozotocin-induced diabetes in mice. Nature 276: 182-184

8. Nedergaard M, Egeberg J, Kromann H (1983) Irradiation protects against pancreatic islet degeneration and hyperglycaemia following streptozotocin treatment of mice. Diabetologia 24: 382-386

9. Blue M-L, Shin S-I (1984) Diabetes induction by subdiabetogenic doses of streptozotocin in BALB/CBOM mice: noninvolvement of host B-lymphocyte functions. Diabetes 33: 105-110

10. Kim YT, Steinberg C (1984) Immunologic studies on the induction of diabetes in experimental animals: cellular basis for the induction of diabetes by streptozotocin. Diabetes 33: 771-777

11. Herold KC, Montag AG, Fitch FW (1987) Treatment with antiT-lymphocyte antibodies prevents induction of insulitis in mice given multiple doses of streptozotocin. Diabetes 36: 796-801

12. Bonnevie-Nielsen V, Lernmark $\AA$ (1986) An H-2 allo-antiserum preserves $\beta$-cell function in mice made diabetic by low-dose streptozotocin. Diabetes 35:570-573

13. Kolb-Bachofen V, Epstein S, Kiesel U, Kolb H (1988) Low-dose streptozotocin-induced diabetes in mice: electron microscopy reveals single-cell insulitis before diabetes onset. Diabetes 37:2127

14. Smith KA (1980) T-cell growth factor. Immunol Rev 51: 337-357

15. Robb RJ, Munck A, Smith KA (1981) T cell growth factor receptors: quantitation, specificity, and biological relevance. J Exp Med 154: 1455-1474

16. Robb RJ, Green WC, Rusk CM (1984) Low and high affinity cellular receptors for interleukin 2: implication for the level of Tac antigen. J Exp Med 160: 1126-1146

17. Lowenthal JW, Corthesy P, Tougne C, Lees R, MacDonald HR, Nabholz M (1985) High and low affinity IL-2 receptors: analysis by IL-2 dissociation rate and reactivity with monoclonal anti-receptor antibody PC61. J Immunol 135: 3988-3994

18. Lowenthal JW, Zubler RH, Nabholz M, MacDonald HR (1985) Similarities between interleukin-2 receptor number and affinity on activated B and T lymphocytes. Nature 315:669-671

19. Moreau J-L, Nabholz M, Diamantstein T, Malek T, Shevach E, Thèze J (1987) Monoclonal antibodies identify three epitope clusters on the mouse p55 subunit of the interleukin 2 receptor: relationship to the interleukin 2-binding site. Eur J Immunol 17: 929-935

20. Malek TR, Robb RJ, Shevach EM (1983) Identification and initial characterization of a rat monoclonal antibody reactive with the murine interleukin 2 receptor-ligand complex. Proc Natl Acad Sci USA 80: 5694-5698

21. Robb RJ, Mayer PC, Garlick R (1985) Retention of biological activity following radioiodination of human interleukin 2: com- parison with biosynthetically labeled growth factor in receptor binding assays. J Immunol Methods 81:1-4

22. Robb RJ (1984) Interleukin 2: the molecule and its function. Immunol Today 5: 203-207

23. Siegel JP, Sharon M, Smith PL, Leonard WJ (1987) The IL-2 receptor $\beta$ chain ( $p 70)$ : role in mediating signals for LAK, NK and proliferating activities. Science 238: 75-78

24. Sharon M, Klausner RD, Cullen BR, Chizzonite R, Leonard WJ (1986) Novel interleukin-2 receptor subunit detected by crosslinking under high affinity conditions. Science 234: 859-863

25. Dukovich M, Wano Y, Thuu LB, Katz P, Cullen BR, Kehrl JH, Green WC(1987) A second human interleukin-2 binding protein that may be a component of high-affinity interleukin-2 receptors. Nature 327:518-522

26. Kolb H (1987) Mouse model of insulin dependent-low dose streptozotocin induced diabetes and nonobese diabetic (NOD) mice. Diab Metab Rev 3: 751-778

27. Oschilewshi M, Schrab E, Kiesel U, Opitz U, Stünkel K, KolbBachofen V, Kolb H (1986) Administration of silica or monoclonal antibody to Thy-1 prevents low-dose streptozotocin-induced diabetes in mice. Immunol Lett 12:289-294

28. Cossel L, Schneider E, Kuttler B, Schmidt S, Wohlrab F, Schade J, Bochmann C (1985) Low dose streptozotocin induced diabetes in mice: metabolic light microscopical, histochemical, immunofluorescence microscopical, electron microscopical and morphometrical findings. Exp Clin Endocrinol 85: 7-26

29. Jacobson MP, Rabinovitch A (1986) Spontaneous diabetes mellitus in the $\mathrm{BB} / \mathrm{W}$ rat: evidence for natural killer cell lysis of islet cells. J Clin Invest 77: 916-924

30. Jacobson JD, Markmann JF, Brayman KL, Barker CF, Naji A (1988) Prevention of recurrent autoimmune diabetes in BB rats by anti-asialo-GM1 antibody. Diabetes 37: 838-841

31. Smith KA (1988) Interleukin-2: inception, impact, and implications. Science 240: 1169-1176

32. Herrmann F, Cannistra SA, Levine H, Griffin JD (1985) Expression of interleukin 2 receptors and binding of interleukin 2 by gamma interferon-induced leukemic and normal monocytic cells. J Exp Med 162: 1111-1116

33. Rubin LA, Kurman CC, Fritz ME, Biddison WE, Boutin B, Yarchoan R, Nelson DL (1985) Soluble interleukin 2 receptors are released from activated human lymphoid cells in vitro. J Immunol 135: 3172-3177

34. Keller RJ, Jackson RA (1989) Developmental regulation of serum interleukin-2 receptor concentrations: attenuation of the childhood peak in patients at risk for developing or having recently developed type I diabetes mellitus. J Pediatr 114: 816-819

35. Giordano C, Panto F, Caruso C, Modica MA, Zambito AM, Sapienza N, Amato MP, Galluzzo A (1989) Interleukin 2 and soluble interleukin 2-receptor secretion defect in vitro in newly diagnosed type I diabetic patients. Diabetes 38:310-315

36. Adams DH, Wang L, Hubscher SG, Elias E, Neuberger JM (1989) Soluble interleukin-2 receptors in serum and bile of liver transplant recipients. Lancet I: 469-471

37. Manoussukis MN, Papadopoulos GK, Prosos AA, Moutsopoulos HM (1989) Soluble interleukin 2 receptor molecules in the serum of patients with autoimmune disease. Clin Immunol Immunopathol 50: 321-332

38. Symnous JA, Wood NC, DiGivine FS, Duff GW (1988) Soluble IL-2 receptor in rheumatoid arthritis. J Immunol 141: 2612-2618

Received: 17 August 1989

and in revised form: 5 February 1990

Dr. K. Yokono

Second Department of Internal Medicine

Kobe University School of Medicine

Chuo-ku, Kobe 650

Japan 